Jurnal Akuntansi dan Bisnis: Jurnal Program studi Akuntansi, 5 (1) Mei 2019.

ISSN 2443-3071 (Print) ISSN 2503-0337 (Online). DOI: 10.31289/iab.v5i1.2441

JURNAL AKUNTANSI DAN BISNIS

Jurnal Program Studi Akuntansi

Available online http://ojs.uma.ac.id/index.php/jurnalakundanbisnis

\title{
PENGARUH REMUNERASI DAN SEMANGAT KERJA TERHADAP KINERJA PEGAWAI PADA KANTOR KEJAKSAAN NEGERI MEDAN
}

\author{
Dito Aditia Darma Nasution $\boldsymbol{a}^{*}$ \\ ${ }^{a}$ Fakultas Sosial Sains, Universitas Pembangunan Panca Budi, Indonesia
}

Diterima April 2019; Disetujui April 2019; Dipublikasikan Mei 2019

\begin{abstract}
Abstrak
Penelitian ini bertujuan untuk melihat pengaruh remunerasi dan semangat kerja terhadap kinerja pegawai baik secara parsial maupun simultan pada Kantor Kejaksaan Negeri Medan. Jenis penelitian yang digunakan adalah penelitian asosiatif/hubungan. Populasi dalam penelitian ini berjumlah 5 unit kerja di Kantor Kejaksaan Negeri Medan yang terdiri dari unit kerja Pembinaan, Pidum, Pidsus, Datun, dan Intel dan yang menjadi sampel penelitian berjumlah 97 orang yang meliputi 18 orang pegawai di unit kerja Pembinaan, 37 orang pegawai di unit kerja Pidum, 18 orang pegawai di unit kerja Pidsus, 9 orang pegawai di unit kerja Datun, dan 15 orang pegawai di unit kerja Intel. Sumber data penelitian ini adalah data primer dengan menggunakan instrument penelitian berupa kuesioner. Metode pengumpulan data yang digunakan adalah penelitian survey. Penelitian ini menggunakan analisis regresi linear berganda untuk analisis statistik dan model regresi telah diuji terlebih dahulu dalam uji asumsi klasik. Hasil penelitian menyatakan bahwa pengujian secara parsial menunjukkan remunerasi berpengaruh positif signifikan terhadap kinerja pegawai pada Kantor Kejaksaan Negeri Medan dan pengujian secara parsial juga menunjukkan semangat kerja berpengaruh positif signifikan terhadap kinerja pegawai pada Kantor Kejaksaan Negeri Medan serta pengujian secara simultan menunjukkan bahwa remunerasi dan semangat kerja berpengaruh signifikan terhadap kinerja pegawai pada Kantor Kejaksaan Negeri Medan.
\end{abstract}

Kata Kunci : Remunerasi, Semangat Kerja, Kinerja Pegawai

\begin{abstract}
This study aims to look at the effect of remuneration and work spirit on employee performance both partially and simultaneously at the Medan District Prosecutor's Office. The research used associative/correlation method. The population was 5 work units at the Medan District Prosecutor's Office consisting of Coaching, Pidum, Pidsus, Datun, and Intel work units and the sample of the study was 97 people including 18 employees in the Coaching work unit, 37 employees in the Pidum work unit, 18 people employees in the Pidsus work unit, 9 employees in the Datun work unit, and 15 employees in the Intel work unit. The data were primary data were obtained by using questionnaires and conducting a survey. The gathered data were analyzed by using multiple linear regression tests for analytical analysis which had been tested by using classic assumption test. The result of the research showed that, partially, Remuneration had positive and significant influence on the Employee Performance at the Medan District Prosecutor's Office and partially, Work Spirit had positive and significant influence on the Employee Performance at the Medan District Prosecutor's Office. Simultaneously, these results indicate that Remuneration and Work Spirit had significant influence on the employee performance at the Medan District Prosecutor's Office.
\end{abstract}

Keyword: Remuneration, Work Spirit, Employee Performance

How To Cite: Nasution, D.A.D. (2019). Pengaruh Remunerasi dan Semangat Kerja terhadap Kinerja Pegawai pada Kantor Kejaksaan Negeri Medan. Jurnal Akuntansi dan Bisnis : Jurnal Program Studi Akuntansi, 5 (1): 71-80 * email: ditoaditia@dosen.pancabudi.ac.id 


\section{PENDAHULUAN}

Sumber daya manusia adalah manusia yang bekerja dilingkungan suatu organisasi disebut juga personil, tenaga kerja, pegawai dan karyawan (Furqan, A 2016). Unsur manusia yang dilihat dari potensinya disebut sumber daya, berbeda dengan sumber daya material. Manusia sebagai sumber daya yang bersifat potensial/abstrak tidak dapat diukur dari jumlahnya. Potensi ini merupakan proses dan hasil interaski substansi fisik dan psikis berupa kemampuan menciptakan, kemampuan berfikir yang menghasilkan gagasan, kretivitas, inisiatif, kemampuan memecahkan masalah, memprediksi, wawasan ke masa depan, keterampilan dan Remunerasi. Dalam sektor publik, manajemen sumber daya manusia berusaha untuk mengungkapkan manusia sebagai sumber daya seutuhnya dalam konsepsi pembangunan bangsa yang utuh dan menyeluruh. Dalam lingkup instansi pemerintah pun, pegawai atau SDM aparatur yang selanjutnya disebut sebagai Pegawai Negeri Sipil memiliki peran penting dalam birokrasi sebagai pelaksanaan utama tugas pemerintah. Sebagai abdi negara dan abdi masyarakat, SDM aparatur tersebut memiliki fungsi inti dalam menyediakan dan memberikan pelayanan yang baik kepada masyarakat. Pelayanan yang diberikan oleh SDM aparatur pun diharapkan mampu menghasilkan inovasi - inovasi baru dengan memberikan pelayanan yang lebih cepat, tepat, mudah, efektif dan efisien, sehingga tercipta kepuasan yang tidak hanya tumbuh dari dalam diri masyarakat sebagai penerima layanan, tetapi juga pada SDM aparatur yang bersangkutan sebagai pemberi layanan (Furqan, A. 2016).

Salah satu filosofi yang terkandung di dalam konsep SDM, yaitu bahwa pegawai dipandang sebagai sebuah investasi bagi institusi, di mana jika karyawan atau pegawai tersebut dikelola dengan perencanaan yang baik dan lebih profesional, maka akan memberikan imbalan bagi institusi dalam bentuk produktivitas yang lebih besar, dan kemungkinan pencapaian tujuan institusi lebih efektif dan efisien. Menurut Triyanto, Dkk (2013) Peningkatan kualitas kinerja sumber daya pegawai sangat diperlukan secara terencana, terarah, dan berkesinambungan dalam rangka meningkatkan kemampuan dan profesionalisme dalam bekerja. Pengembangan kualitas kerja sumber daya pegawai adalah untuk meningkatkan kinerja operasional pegawai dalam melaksanakan tugas tugas pemerintah. Sumber daya pegawai adalah asset utama dalam organisasi yang menjadi pelaku dan perencana aktif dari setiap aktifitas dalam organisasi. Aparatur pemerintah dalam phal ini adalah Pegawai Negeri Sipil (PNS) yang diharapkan memiliki sikap yang profesional, kompeten dan akuntable yang dapat mendukung kondisi pemerintahan yang transparan, demokratis berkeadilan, efektif dn efisien dengan menghormati hukum yang mendorong terciptanya partisipasi dan pemberdayaan.

Menurut Furqan, A (2016) Salah satu upaya peningkatan kinerja adalah menerapkan kebijakan remunerasi dan semangat kerja di lingkungan para aparatur negara. Remunerasi dan semangat kerja bermakna sangat strategis terhadap suksesnya kinerja pegawai mengingat dampak paling signifikan sangat di tentukan oleh perubahan kultur birokerasi didalam melaksanakan tugas pokoknya. Sedangkan keberhasilan merubah kultur tersebut, akan sangat ditentukan oleh tingkat kesejahteraan anggotanya. Martini (2013) juga menjelaskan bahwa remunerasi pemerintah adalah merupakan bagian yang tidak terpisahkan dari kebijakan Reformasi Birokrasi. Di latar belakangi oleh kesadaran sekaligus komitmen pemerintah untuk mewujudkan clean and good governance. Tujuan dari pemberian remunerasi di lingkungan Kejaksaan Negeri Medan ini ialah peningkatan pelayanan hukum kepada masyarakat, peningkatan kesadaran. Menurut Ramadhan dan Syarifuddin (2016) Remunerasi pada dasarnya merupakan salah satu alat untuk mewujudkan visi dan misi organisasi dengan tujuan untuk meningkatkan suatu ikatan kerja sama yang formal antara organisasi dengan pegawai dalam rangka organisasi, 
mengarahkan kemampuan, keterampilan, waktu, serta tenaga yang semuanya ditujukan untuk kepuasan kerja, memberikan rangsangan serta meSemangat Kerja pegawai memberikan kinerja terbaik, remunerasi juga akan mendorong tingkat kedisplinan pegawai dalam bekerja. Menurut Mangkuprawira (2017) Remunerasi mempunyai maskud berupa „sesuatu” yang diterima pegawai sebagai imbalan dari kontribusi yang telah diberikan kepada organisasi tempat bekerja. Remunerasi mempunyai makna yang lebih luas dari pada gaji, karena mencakup semua bentuk imbalan baik secara langsung, maupun tidak langsung, dan bersifat rutin maupun tidak rutin setiap pegawai terhadap organisasinya. Remunerasi juga menjadi salah satu cara dominan bagi organisasi dalam mempertahankan para pegawainya. Dengan remunerasi yang baik, pegawai akan merasa puas dan nyaman sehingga mereka akan bekerja dengan produktif yang pada akhirnya akan membantu organisasi mencapai tujuannya.

Semangat kerja merupakan salah satu faktor individu yang mempengaruhi kinerja dan remunerasi merupakan salah satu faktor organisasi yang mempengaruhi kinerja pegawai. Semangat kerja akan menunjukkan sejauh mana karyawan bergairah dalam melaksanakan tugas dan tanggung jawabnya di dalam perusahaan. Semangat kerja karyawan dapat dilihat dari kehadiran, kedisplinan, ketepatan waktu menyelesaikan pekerjaan dan tanggung jawab. Peranan sumber daya manusia dalam perusahaan sangat penting demi terciptanya kelangsungan kinerja perusahaan (Safitri Pohan, 2017). Faktor semangat kerja harus diketahui oleh para pemimpin perusahaan karena penting artinya bagi keberhasilan suatu usaha dikatakan penting bagi keberhasilan suatu usaha karena semangat kerja dapat memepengaruhi produktivitas dan potensi kerja karyawan. Semangat kerja yang optimal harus didukung dengan keinginan karyawan untuk bekerja secara maksimal.

Kantor Kejaksaan Negeri Medan sebagai salah satu instansi pemerintah, sudah dituntut untuk dapat menyelenggarakan tugas - tugas dan kegiatan secara berdayaguna dan berhasil guna sehingga dapat berhasil menunjukkan citra organisasi pemerintah yang bermutu dan berkualitas. Kejaksaan Negeri Medan adalah lembaga Negara yang melaksanakan kekuasaan negara, khususnya di bidang penuntutan serta sebagai badan yang berwenang dalam penegakan hukum dan keadilan. Dengan adanya tugas berat ini, maka Kejaksaan Negeri Medan harus mampu meningkatkan pelayanan organisasi secara keseluruhan demi memaksimalkan sumber daya yang ada dalam organisasi untuk bekerja lebih baik.

\section{Remunerasi}

Istilah remunersi akhir-akhir ini menjadi trending topic yang hangat diperbincangkan di kalangan pegawai baik itu instansi pemerintah maupun swasta. Remunerasi merupakan bagian dari kompensasi yang diberikan oleh instansi kepada karyawannya. Kompensasi adalah segala sesuatu yang diterima para karyawan sebagai balas jasa untuk hasil kerja mereka (Handoko, 2013). Jadi melalu kompensasi tersebut karyawan dapat meningkatkan prestasi kerja, Semangat Kerja, kinerja serta meningkatkan kebutuhan hidupnya. Menurut Sopiah (2010) Remunerasi diidentifikasi sebagai salah satu faktor yang mempunyai pengaruh terhadap kinerja pegawai dalam menjalankan tugasnya. Remunerasi merupakan imbalan atau balas jasa yang diberikan kepada tenaga kerja atau pegawai sebagai akibat dari prestasi yang telah diberikannya dalam rangka mencapai tujuan organisasi. Dengan remunerasi sendiri, PNS akan dituntut untuk mengoptimalkan kinerjanya karena jumlah remunerasi yang diterima akan sebanding dengan kinerja yang dilakukan, atau dengan kata lain harus memenuhi target tertentu. 
Imbalan atau kompensasi ataupun remunerasi mempunyai cakupan yang lebih luas dari pada upah atau gaji. Imbalan mencakup semua pengeluaran yang dikeluarkan oleh perusahaan untuk pekerja dan diterima atau dinikmati oleh pekerja, baik secara langsung, rutin atau tidak langsung. Program remunerasi, merupakan salah satu program reformasi birokrasi yang telah dicanangkan pemerintah melalui pemberian tunjangan tambahan yang diberikan oleh lembaga sesuai dengan kinerja yang telah dilakukan oleh masing masing pelaku kerja sebagai imbalan atau jasa atas kinerja yang dihasilkan. Salah satu lembaga pemerintah yang sedang mengalami reformasi birokrasi adalah kementrian keuangan. Menurut Yunita Sari dan Rini Handayani (2014), bahwa manusia sebagai makhluk individu dan makhluk sosial mempunyai berbagai macam kebutuhan material maupun non material. Terdapat 7 bentuk remunerasi yaitu gaji, tunjangan biaya hidup (tunjangan pangan dan transport), tunjangan kinerja (insentif), tunjangan hari raya (THR), tunjangan kompensasi, iuran kesehatan, iuran tunjangan hari tua.

Secara harfiah remunerasi diartikan sebagai payment atau penggajian, bisa juga uang atau pun substitusi dari uang yang ditetapkan dengan peraturan tertentu sebagai imbal balik suatu pekerjaan dan bersifat rutin. Dalam konteks perusahaan, remunerasi diartikan sebagai suatu tindakan balas jasa atau imbalan yang diterima karyawan/pekerja dari usaha atas prestasi yang diberikan pekerja dalam rangka mewujudkan tujuan perusahaan (Pora, 2011). Berdasarkan beberapa definisi diatas, penulis menyimpulkan bahwa remunerasi sebagai total kompensasi yang diterima oleh pegawai sebagai imbalan dari jasa yang telah diberikan kepada perusahaan. Bentuk remunerasi biasanya diasosiasikan dengan penghargaan dalam bentuk uang (monetary rewards), atau dapat diartikan juga sebagai gaji yang diberikan kepada pegawai sesuai dengan kinerjanya untuk mewujudkan tujuan perusahaan.

\section{Semangat Kerja}

Seorang karyawan yang memiliki semangat kerja yang baik tentunya akan memberikan sikap yang positif dan keinginan untuk melakukan pekerjaan dengan semangat dan rasa senang. Menurut Badriyah (2015) Semangat kerja adalah kondisi seseorang yang menunjang dirinya untuk melakukan pekerjaan lebih cepat dan lebih baik di sebuah perusahaan. Kondisi melakukan pekerjaan lebih cepat dan lebih baik merupakan gambaran awal dari produktivitas karyawan dalam bekerja. Dengan kata lain, terdapat kecenderungan hubungan langsung antara produktivitas yang tinggi dan semangat yang tinggi.

Menurut Hasibuan (2013), Semangat kerja adalah keinginan dan kesungguhan seseorang mengerjakan pekerjaannya dengan baik serta berdisiplin untuk mencapai prestasi kerja yang maksimal. Semangat kerja ini akan merangsang seseorang untuk berkarya dan berkreativitas dalam pekerjaannya. Indikasi turunnya semangat kerja dapat dilihat dari: rendahnya produktivitas, tingkat absensi yang tinggi, tingkat perputaran karyawan yang tinggi, tingkat kerusakan yang naik, kegelisahan dimana-mana, tuntutan yang sering terjadi, dan pemogokan.

Menurut Nitisemito (2010), semangat kerja adalah melakukan pekerjaan secara lebih giat sehingga pekerjaan dapat diharapkan lebih cepat dan lebih baik. Dapat disimpulkan bahwa semangat kerja merupakan gambaran perasaan, keinginan atau kesungguhan individu/kelompok terhadap organisasi yang akan mempengaruhi 
kedisiplinan dan kesediaan individu dalam kegiatan organisasi untuk mengerjakan tugas dengan lebih baik dan lebih cepat.

\section{Kinerja Pegawai}

Kinerja merupakan suatu kondisi yang harus diketahui dan dikonfirmasikan kepada pihak tertentu untuk mengetahui tingkat pencapaian hasil suatu instansi dihubungkan dengan visi suatu organisasi atau perusahaan serta mengetahui dampak positif dan negatif dari suatu kebijakan operasional. Secara umum, pengertian kinerja adalah hasil pekerjaan yang dicapai seseorang berdasarkan persyaratan-persyaratan pekerjaan. Suatu pekerjaan mempunyai persyaratan tertentu untuk dapat dilakukan dalam mencapai tujuan yang disebut juga sebagai standar pekerjaan. Untuk menentukan kinerja pegawai/karyawan baik atau tidak, tergantung pada hasil perbandingan dengan standar pekerjaan. Hasil pekerjaan merupakan hasil yang diperoleh seorang pegawai atau karyawan dalam mengerjakan pekerjaan sesuai persyaratan pekerjaan atau standar kinerja. Menurut siswanto (2015) yang menyatakan bahwa kinerja adalah kesuksesan seseorang dalam melaksanakan tugas, Pada umumnya, kinerja diberi batasan sebagai kesuksesan seseorang di dalam melaksanakan suatu pekerjaan.

Sedangkan teori lain tentang kinerja menurut Sutrisno (2010) mengemukakan, Kinerja adalah kuantitas, kualitas dan waktu yang digunakan dalam menjalankan tugas. Kuantitas adalah hasil yang dapat dihitung sejauh mana seseorang dapat berhasil mencapai tujuan yang telah ditetapkan. Kualitas adalah bagaimana seseorang dalam menjalankan tugasnya, yaitu mengenai banyaknya kesalahan yamg dibuat, kedisplinan dan ketetapan. Waktu kerja adalah mengenai jumlah absen yang dilakukan, keterlambatan dan lamanya masa kerja dalam tahun yang telah dijalani.

Siswanto (2015) menyebutkan bahwa: "pencapaian kinerja seseorang dinyatakan berkaitan dengan pencapaian serangkaian tugas - tugas individu dengan dukungan pengakuan dan semangat kerja yang diberikan". Sutrisno (2010) juga menyatakan: "kinerja pegawai adalah hasil kinerja secara kualitas dan kuantitas yang dicapai oleh seorang pegawai dalam melaksanakan tugasnya sesuai dengan pengakuan, semangat kerja dan tanggung jawab yang diberikan kepadanya". Adapun pengertian kinerja menurut Bangun (2012) menyatakan kinerja adalah hasil pekerjaan yang dicapai karyawan berdasarkan persyaratan - persyaratan pekerjaan. Seorang pegawai atau karyawan dikatakan berhasil melaksanakan pekerjaannya atau memiliki kinerja baik, apabila hasil kerja yang diperoleh lebih tinggi dari standar kinerja.

\section{METODE PENELITIAN}

Pendekatan penelitian yang dilakukan oleh peneliti adalah dengan menggunakan pendekatan asosiatif dan kuantitatif, hal ini dikarenakan setiap objek yang diteliti memiliki keterkaitan atau hubungan satu sama lainnya. Menurut Sugiyono (2016) penelitian asosiatif bertujuan untuk menganalisis permasalahan hubungan suatu variabel dengan variabel lainnya. Metode penelitian kuantitatif dapat diartikan sebagai metode yang berlandaskan pada filsafat positivism, digunakan untuk meneliti pada populasi atau sampel tertentu, analisis data bersifat kuantitatif atau statistic dengan tujuan untuk menguji hipotesis yang telah ditetapkan. Metode ini disebut dengan metode kuantitatif karena data kuantitatif penelitian berupa angka-angka dan analisis menggunakan statistik, Sugiyono (2016).

Penelitian dilakukan pada Kantor Kejaksaan Negeri Medan, yang menjadi populasi dalam penelitian ini adalah 5 unit kerja di Kantor Kejaksaan Negeri Medan yang terdiri dari unit kerja Pembinaan, Pidum, Pidsus, Datun, dan Intel. Penulis mengambil sampel 
berdasarkan seluruh populasi dalam penelitian ini yaitu seluruh pegawai pada 5 unit kerja di Kantor Kejaksaan Negeri Medan dengan jumlah sampel yaitu berjumlah 97 Orang yang terdiri dari 18 orang pegawai di unit kerja Pembinaan, 37 orang pegawai di unit kerja Pidum, 18 orang pegawai di unit kerja Pidsus, 9 orang pegawai di unit kerja Datun, dan 15 orang pegawai di unit kerja Intel.

Teknik pengumpulan data yang digunakan dalam penelitian ini adalah menggunakan data primer yaitu menggunakan instrumen kuesioner yang telah diuji keabsahannya dengan uji validitas dan uji reliabilitas. Teknik analisis data yang digunakan dalam penelitian ini adalah Regresi Linear Berganda. Menurut Sugiyono (2016) Analisis regresi linear berganda adalah hubungan secara linear antara dua atau lebih variabel independen $\left(\mathrm{X}_{1}, \mathrm{X}_{2}, \ldots \mathrm{X}_{\mathrm{N}}\right)$ dengan variabel dependen $(\mathrm{Y})$. Persamaan regresi dalam penelitian ini dapat dilihat pada rumus sebagai berikut :

$$
\mathrm{Y}=\mathrm{a}+\mathrm{b}_{1} \mathrm{X} 1+\mathrm{b}_{2} \mathrm{X}_{2}+\mathrm{e}
$$

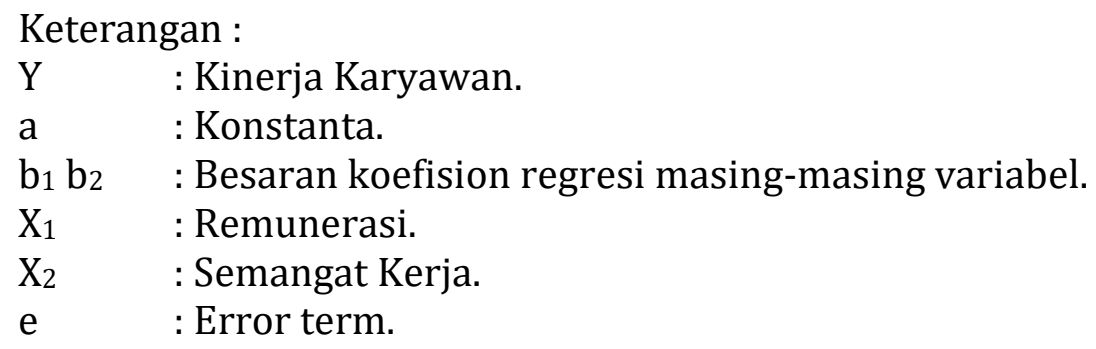

Teknik yang dilakukan dalam menyimpulkan hasil penelitian akan menggunakan yang pertama uji asumsi klasik diperlukan untuk dapat melakukan analisis regresi sederhana. Pengujian tersebut dilakukan untuk menghindari atau mengurangi bias atas hasil penelitian yang diperoleh. Pengujian asumsi klasik yang digunakan dalam penelitian ini meliputi uji normalitas, uji multikolinearitas dan uji autokorelasi (Erlina, 2011). Selanjutnya uji hipotesis melalui Koefisien Determinasi (R2) yakni untuk menentukan apakah model regresi cukup baik digunakan, maka ditetapkan melalui koefisien determinasi. Nilai adjusted R2 dapat naik atau turun apabila satu variabel independen ditambahkan ke dalam model regresi (Ghozali,2006). Uji Statistik t pada dasarnya menunjukkan seberapa jauh satu variabel independen secara individual atau parsial dapat menerangkan variasi variabel terikat.

\section{HASIL DAN PEMBAHASAN}

Uji normalitas bertujuan untuk mengetahui apakah dalam model regresi, variabel penganggu atau residual memiliki distribusi normal atau tidak. Hasil yang diperoleh dapat dilihat pada tabel 1.1 di bawah ini :

Tabel 1.1 Uji Normalitas 


\begin{tabular}{llc}
$\begin{array}{l}\text { One-Sample Kolmogorov-Smirnov } \\
\text { Test }\end{array}$ & & Unstandardized Residual \\
\hline $\mathrm{N}$ & & 97 \\
Normal Parametersa & Mean & .0000000 \\
& Std. Deviation & 1.59197148 \\
Most Extreme Differences & Absolute & .070 \\
& Positive & .070 \\
& Negative & -.067 \\
Kolmogorov-Smirnov Z & & .693 \\
Asymp. Sig. (2-tailed) & & .722 \\
\hline
\end{tabular}

a. Test distribution is Normal.

Berdasarkan table 1.1 di atas, dari hasil uji probabilitas dapat dilihat pada nilai Asymp. Sig. (2 tailed) nilanya 0,722 dimana $>0,05$ yang artinya data berdistribusi secara normal.

Tabel 1.2 Uji statistik

\begin{tabular}{|c|c|c|c|c|c|c|c|c|}
\hline \multirow[t]{2}{*}{ Keterangan } & \multicolumn{2}{|c|}{$\begin{array}{c}\text { Multicollinearity } \\
\text { Statistics }\end{array}$} & \multicolumn{2}{|c|}{ Heterokedastisiti } & \multicolumn{2}{|c|}{$\begin{array}{l}\text { Unstandardized } \\
\text { Coefficients }\end{array}$} & \multicolumn{2}{|c|}{ T-test Value } \\
\hline & Tolerance & VIF & $\mathrm{t}$ & Sig. & B & $\begin{array}{l}\text { Std. } \\
\text { Error }\end{array}$ & $\mathrm{t}$ & Sig. \\
\hline \multirow{3}{*}{$\begin{array}{l}\text { Constant } \\
\text { Remunerasi } \\
\text { Semangat Kerja }\end{array}$} & & & & & 18.117 & 2.850 & 6.356 & .000 \\
\hline & .998 & 1.002 & .721 & .473 & .111 & .046 & 2.419 & .018 \\
\hline & .998 & 1.002 & -.150 & .881 & .292 & .062 & 4.673 & .000 \\
\hline
\end{tabular}

Dependent Variable: Kinerja Pegawai

Berdasarkan hasil uji multikolinearitas pada tabel 1.2 dapat diketahui bahwa tidak ada variabel independen yang memiliki nilai VIF $>10$ dan nilai tolerance $<0,1$ sehingga disimpulkan bahwa pada model tidak terjadi multikolinearitas. Selanjutnya, hasil uji Glejser heteroskedastisitas pada tabel 1.2 menunjukkan nilai signifikansi untuk setiap variabel bebas lebih besar dari 0,05 dengan demikian dapat disimpulkan tidak terjadi heteroskedastisitas dalam model. Analisis regresi linier berganda dilakukan untuk mengetahui pengaruh Remunerasi dan Semangat Kerja terhadap Kinerja Pegawai. Dari pengelolaan data diperoleh hasil dijabarkan pada tabel 1.2 diatas

Berdasarkan tabel 1.2 di atas, maka persamaan regresi linier berganda dalam penelitian ini adalah sebagai berikut :

$$
\mathrm{Y}=18,117+0,111 \mathrm{X}_{1}+0,292 \mathrm{X}_{2}+\mathrm{e}
$$

Pada model regresi ini, nilai konstanta yang tercantum sebesar 18,117 artinya jika Remunerasi dan Semangat Kerja dalam model diasumsikan sama dengan 0, maka Kinerja Pegawai sama dengan 18,117. Nilai koefisien regresi variabel remunerasi bernilai positif yaitu 0,111 berarti bahwa setiap peningkatan Remunerasi sebesar 1\%, maka akan meningkatkan Kinerja Pegawai sebesar 0,111 atau 11,1\%. Nilai koefisien regresi variabel semangat kerja bernilai positif yaitu 0,292 berarti bahwa setiap peningkatan Semangat Kerja sebesar 1\%, maka akan meningkatkan Kinerja Pegawai sebesar 0,292 atau 29,2\%. Hasil uji $\mathrm{t}$ menunjukkan variabel independen secara parsial berpengaruh terhadap variabel dependen, jika $p$-value (pada kolom sig.) lebih kecil dari level of significant yang 
ditentukan (sebesar 5\%), atau t hitung (pada kolom $t$ ) lebih besar dari t tabel. $t$ tabel dihitung dengan cara $\mathrm{df}=\mathrm{n}-\mathrm{k}$, yaitu $\mathrm{df}=97-3=94$, sehingga diperoleh nilai $\mathrm{t}$ tabel sebesar 1,986. Sedangkan hasil uji t dengan bantuan program SPSS dapat dilihat pada tabel $1.6 \mathrm{di}$ bawah ini:

Berdasarkan analisis hasil uji t dari tabel 1.2 maka secara parsial pengaruh masingmasing variabel independen terhadap variabel dependen dapat diuraikan yaitu hasil uji parsial terhadap pengaruh variabel Remunerasi terhadap Kinerja Pegawai menunjukkan adanya pengaruh signifikan dan positif. Hal ini dapat diketahui dari nilai signifikan 0,018 $<$ dari alpha 0,05 dan nilai t hitung lebih besar dari t tabel $(2,419>1,986)$ dan hasil uji parsial terhadap pengaruh variabel Semangat Kerja terhadap Kinerja Pegawai juga menunjukkan adanya pengaruh signifikan dan positif. Hal ini dapat diketahui dari nilai signifikan 0,000 < dari alpha 0,05 dan nilai t hitung lebih besar dari t tabel $(4,673>1,986)$.

\section{Koefisien Determinasi (R2)}

Menurut Ghozali (2012) analisis koefisien determinasi $\left(\mathrm{R}^{2}\right)$ merupakan: "alat untuk mengukur seberapa jauh kemampuan model dalam menerangkan variasi variabel dependen". Hasil olahan program SPSS dalam analisis koefisien determinasi $\left(\mathrm{R}^{2}\right)$ dapat dilihat secara jelas pada tabel 1.3 sebagai berikut :

Tabel 1.3 Koefisien Determinasi

\begin{tabular}{|c|c|c|c|c|}
\hline & & $\mathrm{R}$ & Adjusted & Std. Error of the \\
\hline Model & $\mathrm{R}$ & Square & Square & Estimate \\
\hline 1 & $.484^{a}$ & .234 & .218 & 1.609 \\
\hline
\end{tabular}

Pada tabel 1.5 koefisien determinasi $\left(\mathrm{R}^{2}\right)$ menunjukkan bahwa nilai R sebesar 0,484 yang berarti korelasi hubungan antara variabel dependen dengan variabel independen cukup kuat karena $\mathrm{R}>48 \%(0,484)$. Variabel yang lebih dari dua maka yang digunakan adalah Adjust $R$ Square (Situmorang, et, al. 2010). Penelitian ini menggunakan lebih dari dua variabel, maka yang digunakan adalah Adjust $R$ Square sebesar 0,218 yang mengindikasikan bahwa 21,8\% variabel dependen (Kinerja Pegawai) dipengaruhi oleh variabel independen (Remunerasi dan Semangat Kerja), sedangkan sisanya sebesar 78,2\% (100\%-21,8\%) dijelaskan oleh variabel lain diluar model estimasi yang tidak diteliti dalam penelitian ini.

\section{Hasil Uji F}

Hasil uji F menunjukkan variabel independen secara bersama-sama berpengaruh terhadap variabel dependen, jika $p$-value (pada kolom sig.) lebih kecil dari level of significant yang ditentukan (sebesar 5\%), atau F hitung (pada kolom F) lebih besar dari F tabel. F tabel dihitung dengan cara df1=k-1, dan df2=n-k, yaitu df $1=3-1=2$ dan df2=973=94, sehingga diperoleh nilai $F$ tabel sebesar 3,093. Sedangkan hasil uji F dengan bantuan program SPSS dapat dilihat pada tabel 1.7 di bawah ini : 
Tabel 1.4 Hasil Uji F melalui ANOVA

\begin{tabular}{|c|c|c|c|c|c|c|}
\hline \multirow[t]{4}{*}{ Model } & & $\begin{array}{l}\text { Sum of } \\
\text { Squares }\end{array}$ & $\mathrm{df}$ & Square $^{\text {Mean }}$ & $\mathrm{F}$ & Sig. \\
\hline & Regression & 74.453 & 2 & 37.226 & 14.383 & $.000^{\mathrm{a}}$ \\
\hline & Residual & 243.300 & 94 & 2.588 & & \\
\hline & Total & 317.753 & 96 & & & \\
\hline
\end{tabular}

Predictors: (Constant), Semangat Kerja, Remunerasi

Dependent Variable: Kinerja Pegawai

Pada tabel 1.4 diatas terlihat bahwa besaran nilai $\mathrm{F}$ hitung $(14,383)>$ dari $\mathrm{F}$ tabel $(3,093)$ dengan tingkat signifikan sebesar $0,000<0,05$. Hasil ini menunjukkan bahwa uji hipotesis menerima $\mathrm{H}_{\mathrm{a}}$ dan menolak $\mathrm{H}_{0}$, sehingga dapat diketahui bahwa variabel independen Remunerasi (X1) dan Semangat Kerja (X2) secara simultan berpengaruh terhadap variabel dependen Kinerja Pegawai (Y) pada Kantor Kejaksaan Negeri Medan.

\section{SIMPULAN}

Berdasarkan analisis data dan pembahasan dapat disimpulkan bahwa nilai Adjust $R$ Square sebesar 0,218 yang mengindikasikan bahwa 21,8\% variabel dependen (Kinerja Pegawai) dipengaruhi oleh variabel independen (Remunerasi dan Semangat Kerja), sedangkan sisanya sebesar 78,2\% dijelaskan oleh variabel lain diluar model estimasi yang tidak diteliti dalam penelitian ini. Berdasarkan hasil uji t, remunerasi berpengaruh positif signifikan terhadap kinerja pegawai pada Kantor Kejaksaan Negeri Medan dan semangat kerja juga berpengaruh positif signifikan terhadap kinerja pegawai pada Kantor Kejaksaan Negeri Medan. Berdasarkan hasil uji F, remunerasi dan semangat kerja berpengaruh signifikan terhadap kinerja pegawai pada Kantor Kejaksaan Negeri Medan. Dari simpulan ini menunjukkan juga bahwa pegawai yang memiliki kinerja yang baik dapat dipastikan dipengaruhi oleh pemberian remunerasi yang sesuai dan kinerja yang baik juga berdampak dari semangat kerja pegawai pada Kantor Kejaksaan Negeri Medan.

\section{DAFTAR PUSTAKA}

Adnyani ( 2010). "Membina Semangat Kerja Untuk Meningkatan Produktivitas Kerja Karyawan”. Buletin Studi Ekonomi Vol .13 Tahun 2016.

Alex, S Nitisemito (2010). Manjemen Personalia. Jakarta : Ghalia Indonesia.

Arfan Ikhsan Lubis (2010). Akuntansi Keprilakuan Edisi 2. Jakarta : Salemba Empat.

Bangun Wilson (2012). Mnajemen Sumber Daya Manusia. Jakarta : Erlangga.

Badriyah, M (2015). Manajemen Sumber Daya Manusia. Cetakan 1. Bandung : CV Pustaka Setia.

Bernhard Tewal (2014). "Pengaruh Konflik Peran Terhadap Kinerja Wanita Karir Pada Universitas Sam Ratulangi Manado". Jurnal EMBA Vol 2 No 1 Tahun 2014.

Boedianto, Sugeng (2012). "Pengaruh Pemberian Remunerasi Terhadap Kinerja Pegawai Lapas Klas IIA Anak Blitar.

Boy, Chrisdoni Agung Pasaribu (2013).”Pengaruh Remunerasi dan Semangat Kerja Berprestasi Terhadap Kinerja Pegawai Pada Kantor Pengawasan dan Pelayanan Bea Cukai Medan Sumatera Utara".

D. Siswanto Sastrohadiwiryo (2010). Manajemen Tenaga Kerja Indonesia pendekatan Administrasi dan Operasional. Jakarta : Bumi Aksara.

De Pora, Antoni (2011). Remunerasi, Kompensasi dan Benefit. Jakarta : Rana Pustaka.

Deseller, Gary (2010). Manajemen Sumber Daya Manusia. Jakarta: PT. Indeks.

Eko Triyanto (2013). "Peran Kepemimpinan Kepala Sekolah Dalam Pemanfaatan Media Pembelajaran Sebagai Upaya Peningkatan Kualitas Proses Pembelajaran”. Jurnal Teknologi Pendidikan.

Furqan, Achmad (2016). “Pengaruh Remunerasi Terhadap Kinerja Pegawai Pada Kantor Pelayanan Pajak Pratama Makassar Utara".

Hani Handoko (2010). Manajemen (Edisi2). Yogyakarta: BPFE. Yogyakarta. 
Nasution, D.A.D. (2019). Pengaruh Remunerasi dan Semangat Kerja terhadap Kinerja Pegawai pada Kantor Kejaksaan Negeri...

Handoko, T.Hani (2010). Manajemen Personalia dan Sumber daya Manusia. Yogyakarta: BPFE. Yogyakarta.

Iman Indra \& Siswandi (2010). Aplikasi Manajemen Perusahaan Analisis Kasus dan Pemecahannya. Jakarta: Mitra Wacana Media.

Istijanto, Oei (2010). Riset Sumer Daya Manusia. Jakarta: PT Gramedia Pustaka Utama.

James, Dkk (2010). Lecture Notes Oftalmologi Edisi 9. Alih Bahasa dr. Asri D, Rachmawati. Jakarta: Penerbit Erlangga.

Juliandi A, Irfan dan Manurung S (2015). Metodologi Penelitian Bisnis. Medan : UMSU PRESS.

Mangkunegara. A.P (2013). Manajemen Sumber Daya Manusia Perusahaan. Bandung: PT. Remaja Rosdakarya.

Mathis, Robert L. \& John H.Jackson (2010). Manajemen Sumber Daya Manusia. Jakarta : Salemba Empat.

Mahmudi (2010). Manajemen Keuangan Daerah. Jakarta : Erlangga.

Mega Suryani (2016). "Pengaruh Semangat Kerja dan Remunerasi Terhadap Kinerja Pegawai Dengan Gaya Kepemimpinan Sebagai Variabel Moderating Pada Kantor wilayah Kementerian Hukum dan Ham Lampung".

Misail Palagia, dkk. (2012). "Remunerasi, Semangat Kerja Dan Kepuasan Kerja Terhadap Kinerja Pegawai Pada Kantor Pajak". Jurnal Analisis 2012.

Muhammad Ramadhan, Syarifuddin (2016), "Pengaruh Remunerasi Terhadap Kinerja Pegawai Dinas Kelautan dan Perikanan Kabupaten Tangerang". Vol.3, No.2 Tahun 2016.

Nasution, D. A. D. (2016). Analisis Faktor-faktor yang Mempengaruhi Implementasi SAP Berbasis Akrual dengan Komitmen SKPD sebagai Variabel Moderating pada Pemerintah Provinsi Sumatera Utara (Tesis). Universitas Sumatera Utara. Medan.

Rina Martini (2013). "Remunerasi Dan Rasa Keadilan Masyarakat". Jurnal Ilmu Pemerintahan.

Risni Fitria, dkk (2014). "Pengaruh Remunerasi, Semangat Kerja dan Kepuasan Kerja Terhadap Kinerja Pegawai Di Kantor Pengadilan Tinggi Negeri Samarinda”. e-Jurnal Administrative Reform Vol. 2 No. 3 Tahun 2014.

Robbins SP, Judge (2012). Perilaku Organisasi Buku 2. Jakarta: Salemba Empat.

Safitri Pohan (2017). "Pengaruh Konflik Kerja dan Semangat Kerja Terhadap Kinerja Karyawan Pada PT. Anugrah Boinda Lestari Medan". Jurnal 2013.

Saifudin Azwar (2012). Penyusunan Skala Psikologi Bandung: Ciptapustaka Media.Perintis.

Setiawan F \& Kartika Dewi A (2014). "Pengaruh Kompensasi dan Lingkungan Kerja Terhadap Kinerja Karyawan Pada CV. Berkat Anugrah" E-Jurnal Manajemen Universitas Udayanar.

Sopiah (2010). Perilaku Organisasi. Yogyakarta: ANDI. Yogyakarta.

Suhendri (2014). "Pengaruh Kompensasi Dan Semangat Kerja Terhadap Kinerja Karyawan Pada Pt. Tunas Jaya Utama".

S.P, Hasibuan, Malayu (2013). Manajemen Sumber Daya Manusia. Jakarta: PT Bumi Aksara.

Supriyanto, Edi (2013). "Pengaruh Penetapan Sasaran Dan Sistem RemunerasiTerhadap Kinerja Pegawai Organisasi Sektor Publik".

Suyadi Prawirosentono (2010). Manajemen Sumber Daya Manusia Kebijakan Kinerja Karyawan. Yogyakarta: BPFE. Yogyakarta.

Sutrisno Edy (2010). Budaya Organisasi. Jakarta: Kencana Prenada Media Group.

Sugiyono (2016). Metode Penelitian Kuantitatif Kualitatif dan Kombinasi (mixed Methods). Bandung : Alfabeta.

Sondang. P. S (2013). Manajemen Sumber Daya Manusia. Jakarta: Bumi Akasara.

Simamora (2010). Manajemen Sumber Daya Manusia. Jakarta: Mitra Wacana Media.

Tb. Sjafri Mangkuprawira (2017). Manajemen Sumber Daya Manusia Trategik. Bogor: Ghalia Indonesia.

Tohardi, Ahmad (2012). Pemahaman Praktis Manajemen Sumber Daya Manusia. Bandung: CV. Mandar Maju.

Wirawan (2010). Evaluasi Kinerja Sumber Daya Manusia Teori Aplikasi dan Penelitian. Jakarta : Salemba Empat.

Yahyo, Handoyo Djoko W \& Reni Shinta Dewi (2013). “Pengaruh Semangat Kerja Lingkungan Kerja, dan Kompensasi terhadap Kinerja Karyawan melalui Semangat Kerja Karyawan (Studi Kasus pada Karyawan Melalui Produksi CV. Putra Jaya Sahitaguna, Semarang).

Yunita Sari Mustikaningsih dan Rini Handayani (2014). "Pengaruh Gaya Kepemimpinan, Budaya Organisasi, Komitmen Organisasi dan Remunerasi Terhadap Kinerja Karyawan”. Media Ekonomi Dan Manajemen. 